\title{
Research Article \\ Effect of Management of Sulfonylurea Resistant Stellaria media on Barley Yield
}

\author{
Tuomas Uusitalo, ${ }^{1,2}$ Asmo Saarinen, ${ }^{3}$ and Pirjo S. A. Mäkelä ${ }^{1}$ \\ ${ }^{1}$ Department of Agricultural Science, P.O. Box 27, University of Helsinki, 00014 Helsinki, Finland \\ ${ }^{2}$ Raisioagro Oy, P.O. Box 101, 21201 Raisio, Finland \\ ${ }^{3}$ Berner Oy, Eteläranta 4B, 00130 Helsinki, Finland
}

Correspondence should be addressed to Pirjo S. A. Mäkelä; pirjo.makela@helsinki.fi

Received 1 October 2013; Accepted 26 November 2013

Academic Editors: M. Ruiz and S. S. Xu

Copyright (C) 2013 Tuomas Uusitalo et al. This is an open access article distributed under the Creative Commons Attribution License, which permits unrestricted use, distribution, and reproduction in any medium, provided the original work is properly cited.

\begin{abstract}
Sulfonylureas represent one of the largest herbicide groups that have been widely used since 1980s. Their continuous use has resulted in development of sulfonylurea resistance in weeds. The aim of this research was to investigate options to manage putative sulfonylurea-resistant chickweed in barley stands and to evaluate the effect of chickweed and its management on barley yield. A field experiment was arranged as a randomized complete block design and included 14 herbicide treatments applied at two different times. Tribenuron-methyl (sulfonylurea) affected minimal control of chickweed. A bromoxynil-ioxynil (photosystem II inhibitor) mix did not control chickweed efficiently. However, nearly total control was achieved with fluroxypyr, mecoprop, and their mixtures (synthetic auxins and photosystem II inhibitors). Chickweed had no effect on barley yield whether controlled or uncontrolled. Therefore, further evaluation of the chickweed management threshold would be needed. It seems that even in the boreal region, typified by a cold climate, limited solar radiation, a very short growing season, and relatively low-intensity cropping systems, unilateral use of sulfonylureas might lead to herbicide resistance. Although resistant weed populations can be controlled with herbicides of groups other than the sulfonylureas, this represents an increasing problem when planning weed management, especially when including sulfonylurea-resistant crops.
\end{abstract}

\section{Introduction}

Acetolactate synthase (ALS) inhibitors were commercialized in 1982, chlorsulfuron being one of the first active ingredients used. They quickly spread around the world and, due to their selectivity, low application rate, and broad-spectrum effectiveness, in many cases came to represent a key component of weed management [1]. Sulfonylureas belong to the group of ALS inhibitors. Widespread reliance solely on sulfonylureas has led to a situation where by 1998 large numbers of weed species were reported to be resistant to sulfonylureas [2]. Sulfonylurea-resistant weed species currently number over 100 [1]. The first reported sulfonylurea-resistant weed, prickly lettuce (Lactuca serriola L.), in 1987 was resistant to chlorsulfuron [3]. This was followed in 1988 by a common chickweed [Stellaria media (L.) Vill.] population in Canada [4]. In the northern temperate region (Norway and Sweden)
ALS-resistant chickweed has been reported from Sweden in 1995 and Norway in 2002 (www.weedscience.com) but not in the northern boreal region (e.g., Finland).

Sulfonylurea resistance derives mainly from a singlepoint mutation in the ALS gene, which leads to substitutions in branched-chain amino acids [1]. In some cases the mutation can lead to cross-resistance against other ALSinhibitor herbicides [5]. Some weeds, such as rigid ryegrass (Lolium rigidum Gaud) and blackgrass (Alopecurus myosuroides Huds.), have also developed non-target-site cross-resistance across several herbicide modes of action, including ALS inhibitors and other herbicide groups never used in the areas in which the resistant weeds have been found [1].

Further development and spread of sulfonylurea resistance in weeds could be prevented, or at least reduced, through the use of herbicides belonging to groups with 
different modes of action, as well as by applying herbicide mixtures [6]. Effective crop management practices, such as attempts to reduce the weed seed bank and diversified weed management systems, are feasible options to reduce the problem of development of herbicide resistance [7]. Increased attention should be paid, however, to the use of clean seed and equipment, and use of crop rotations and cover crops [8].

Chickweed, originally from Europe, is distributed globally. In Northern Europe chickweed is one of the most common weeds in spring and winter cereal stands, with a cool and humid climate favoring its growth [9]. Chickweed is adapted to low light intensities and thus grows well under the shade of a crop canopy [10]. Moreover, root growth of chickweed is faster than, for example, that of barley (Hordeum vulgare L.) and chickweed takes up nitrogen more effectively than barley [11] and can out-compete cereal and oilseed crops for resources, resulting in yield and quality losses [12].

The aims of the work were to evaluate the effect of sulfonylurea-resistant chickweed and its management options on barley stands in most northern agricultural areas in the boreal region [13].

\section{Materials and Methods}

A field experiment was conducted in 2012 in Somero $\left(60^{\circ} 70,63^{\prime} \mathrm{N}, 23^{\circ} 23,59^{\prime} \mathrm{E}, 80 \mathrm{~m}\right.$ asl $)$. The soil type was a rich loamy silt loam, pH 5.9. The field had a long history of cereal and oilseed production, and sulfonylureas were mainly used to control weeds. In 2010 and 2011, substantial chickweed populations developed following herbicide treatment. Seed samples were collected in 2010 and analyzed at DuPont, Germany, for herbicide resistance. Results indicated that the chickweed populations had developed sulfonylurea resistance.

Barley (cv. NCF-Tipple) was sown on May 10, 2012, at 500 seeds $/ \mathrm{m}^{2}$ and was fertilized with $108 \mathrm{~kg} / \mathrm{ha} \mathrm{N}$ (N-P-K : $27-$ 2-3; Pellon Y1, Yara Finland) at sowing. Herbicides were applied either early, 28 days after sowing (DAS), at growth stage 21 of barley [14] and growth stage 10-16 for chickweed, or late, $41 \mathrm{DAS}$, at growth stage 30 of barley and growth stage 20 for chickweed. There were 14 specific herbicide treatments (Table 1) and water was applied as a control. Herbicides were chosen to represent the ALS-inhibiting group (both sulfonylureas and nonsulfonylureas), synthetic auxins, and the photosystem II-inhibiting group. Application rates ranged from the lowest to the highest recommendations. Diseases were controlled twice during the growing season, first (stage 31) with $0.5 \mathrm{~L} /$ ha Prosaro EC 250 (prothioconazole $125 \mathrm{~g} / \mathrm{L}$ and tebuconazole $125 \mathrm{~g} / \mathrm{L}$, Bayer Crop Science) and later (stage 39) with $0.25 \mathrm{~L} /$ ha Comet (pyraclostrobin $250 \mathrm{~g} / \mathrm{L}$, BASF) and $0.25 \mathrm{~L} /$ ha Sportak $45 \mathrm{HF}$ (prochlorazine $450 \mathrm{~g} / \mathrm{L}$, BASF). A growth regulator $(0.6 \mathrm{~L} /$ ha Terpal, mepiquat chloride $305 \mathrm{~g} / \mathrm{L}$, and etefon $155 \mathrm{~g} / \mathrm{L}, \mathrm{BASF}$ ) was applied after the initial fungicide application (stage 32).

Botanical analysis of weeds was conducted before treatments were applied. Since chickweed was practically the only weed present (Table 2), no further attention was paid to other weeds. The population density of chickweed was assessed from an area of $0.1 \mathrm{~m}^{2}$ from each plot one day before each herbicide treatment and 14 and 28 days after herbicide treatment. Biomass samples of chickweed were collected 35 days after the late herbicide treatment. An area of $0.25 \mathrm{~m}^{2}$ was cut above the soil surface and chickweed plants were dried at $65^{\circ} \mathrm{C}$ for two days, weighed, ground, and stored at room temperature for further analysis. The nitrogen $(\mathrm{N})$ content of chickweed was analyzed from ground biomass samples using the Dumas combustion method (Elementar Vario Max $\mathrm{C} / \mathrm{N}$, Elementar Analysensysteme GmbH, Hanau, Germany). The height of the chickweed population was measured, and the weed coverage and treatment efficiency were evaluated visually 42 days after the late herbicide treatment using an 11 -step scale (e.g., 0 , no weeds; $3,1-5 \% ; 15,10-22 \% ; 30,22-$ $40 \%$; 50, 40-60\%; 70, 60-78\%; 85, 78-90\%; 97, 95-99\%; 100, full coverage). At maturity, barley was harvested. Grain was sorted and weighed, and the test weight and moisture content were recorded. Protein content was analyzed using a near infrared spectrometer (DA7200 NIR Analyser, Perten Instruments, Sweden). The experiment was arranged in a completely randomized block design with four replications. Plot size was $33 \mathrm{~m}^{2}(3 \times 11 \mathrm{~m})$.

Data for analyzed traits were subjected to ANOVA using the PASW 18.0 program (IBM Chicago, IL, USA) to compare the effects of herbicide treatments. Statistically significant differences among treatment means were established using Tukey's test.

\section{Results and Discussion}

The population density of chickweed decreased substantially following herbicide treatments, to a greater extent when evaluated 28 days after treatment (Table 3) than 14 days after treatment (data not shown). The only exception among herbicide treatments was tribenuron-methyl, which did not have a markedly different effect from the control, bromoxynilioxynil mix, and a low application rate of florasulam, which reduced the population density by only approximately $50 \%$ (Table 3). A similar decreasing trend was noted for chickweed biomass, since it was only approximately $25 \%$ lower following tribenuron-methyl and bromoxynil-ioxynil mix treatment in comparison with the control (Table 3). However, tribenuronmethyl should be more than $90 \%$ efficient against chickweed [5]. It can therefore be suggested that the chickweed population developed resistance against sulfonylureas, especially with the earlier confirmation of existence of sulfonylurea resistance by DuPont seed testing. Since the efficiency of tribenuron-methyl against chickweed was about 50\%, it seems that the population contains resistant and nonresistant plants.

Similarly to the reports of Kudsk et al. [5] and Marshall et al. [15], fluroxypyr and mecoprop-P were effective against chickweed (Table 3). Fluroxypyr was effective even when applied at low application rates and at late growth stages on larger plants (Table 3). The best chickweed control was at the highest application rate of fluroxypyr and mecoprop-P, after the application of which practically all chickweed plants were destroyed (Table 3$)$. The lowest application rate (54 g/ha) 
TABLE 1: Trade names, active ingredients and their concentrations, and the concentrations of active ingredients applied in the field experiment in 2012. All herbicides were applied as an aqueous solution at $150 \mathrm{~L} / \mathrm{ha}$.

\begin{tabular}{lccc}
\hline Active ingredient & Trade name & \multicolumn{2}{c}{ Active ingredient applied } \\
& & $\mathrm{g} / \mathrm{L}$ or g/g & $\mathrm{g} / \mathrm{ha}$ \\
\hline Bromoxynil: ioxynil & Oxitril EC & $200: 200$ & $100: 100$ \\
Bromoxynil : ioxynil & Oxitril EC & $200: 200$ & $150: 150$ \\
Bromoxynil : ioxynil & Oxitril EC & $200: 200$ & $200: 200$ \\
Dichlorprop-P:MCPA : mecoprop-P & K-Trio SL & $310: 160: 130$ & $310: 160: 130$ \\
Dichlorprop-P:MCPA : mecoprop-P & K-Trio SL & $310: 160: 130$ & $465: 240: 195$ \\
Dichlorprop-P:MCPA : mecoprop-P & K-Trio SL & $310: 160: 130$ & $620: 320: 260$ \\
Florasulam & Primus SC & 50 & 2.5 \\
Florasulam & Primus SC & 50 & 3.75 \\
Florasulam & Primus SC & 50 & 5 \\
Fluroxypyr & Starane 180 EC & 180 & 180 \\
Fluroxypyr & Starane 180 EC & 180 & 54 \\
Fluroxypyr & Starane 180 EC & $200: 20: 40$ & 108 \\
MCPA : clopyralid : fluroxypyr & Ariane S SL & 0.5 & $400: 20: 80$ \\
Tribenuron-methyl & Express 50 SX & 10 \\
\hline
\end{tabular}

TABLE 2: Botanical analysis and number of weeds in barley plant stands before herbicide treatments in 2012.

\begin{tabular}{lcc}
\hline Scientific name & Common name & Number of plants $/ \mathrm{m}^{2}$ \\
\hline Stellaria media $(\mathrm{L}$.$) Vill.$ & Common chickweed & 237 \\
Lamium purpureum L. & Red deadnettle & 2 \\
Fumaria officinalis $\mathrm{L}$. & Common fumitory & 1 \\
Chenopodium album L. & Common lamb's quarter & $<1$ \\
Fallopia convolvulus L. & Wild buckwheat & $<1$ \\
\hline
\end{tabular}

TABLE 3: Reduction in common chickweed population density, coverage of common chickweed, and treatment efficiency against common chickweed evaluated after herbicide treatments in a field experiment in 2012.

\begin{tabular}{|c|c|c|c|c|c|c|}
\hline \multicolumn{2}{|l|}{ Applied treatment } & \multicolumn{2}{|c|}{ Density reduction, $\%$} & \multirow{2}{*}{ Treatment efficiency, \% } & \multirow{2}{*}{ Coverage, $\%$} & \multirow{2}{*}{ Biomass, $\mathrm{g} / \mathrm{m}^{2}$} \\
\hline Active ingredient & $\mathrm{g} / \mathrm{ha}$ & 28 DAS & $41 \mathrm{DAS}$ & & & \\
\hline Control & 0 & 4 & +22 & 0 & 99 & 61.37 \\
\hline Bromoxynil : ioxynil & $100: 100$ & 42 & 38 & 54 & 67 & 13.02 \\
\hline Bromoxynil : ioxynil & $150: 150$ & 49 & 44 & 76 & 41 & 5.34 \\
\hline Bromoxynil : ioxynil & $200: 200$ & 65 & 64 & 82 & 42 & 3.20 \\
\hline Dichlorprop-P : MCPA : mecoprop-P & $310: 160: 130$ & 83 & 94 & 97 & 5 & 0.25 \\
\hline Dichlorprop-P : MCPA : mecoprop-P & $465: 240: 195$ & 86 & 98 & 98 & 4 & 0.17 \\
\hline Dichlorprop-P : MCPA : mecoprop-P & $620: 320: 260$ & 89 & 97 & 99 & 2 & 1.82 \\
\hline Florasulam & 2.5 & 54 & 84 & 97 & 5 & 0.46 \\
\hline Florasulam & 3.75 & 62 & 89 & 98 & 4 & 0.33 \\
\hline Florasulam & 5 & 68 & 91 & 98 & 3 & 0.03 \\
\hline Fluroxypyr & 54 & 63 & 75 & 89 & 30 & 6.03 \\
\hline Fluroxypyr & 108 & 82 & 95 & 98 & 4 & 0.31 \\
\hline Fluroxypyr & 162 & 86 & 100 & 99 & 2 & 0.02 \\
\hline MCPA : clopyralid : fluroxypyr & $400: 20: 80$ & 84 & 97 & 97 & 4 & 0.16 \\
\hline \multirow[t]{2}{*}{ Tribenuron-methyl } & 10 & 28 & 20 & 47 & 69 & 20.01 \\
\hline & S.E.M. & $5.9^{* * *}$ & $6.0^{* * *}$ & $6.9^{* * *}$ & $8.7^{* * *}$ & $3.847^{* * *}$ \\
\hline
\end{tabular}

*** Statistically significant at $P=0.001$.

Data shown are combined means of early and late herbicide treatments $(n=8)$, except for reduction data means $(n=4)$, since there were no significant differences between timings of treatment. 
TABLE 4: Barley grain yield and its protein content following herbicide treatments in the field experiment of 2012.

\begin{tabular}{|c|c|c|c|c|}
\hline \multicolumn{2}{|l|}{ Applied treatment } & \multirow{2}{*}{ Yield, kg/ha } & \multirow{2}{*}{ Test weight, hL } & \multirow{2}{*}{ Protein content, $\%$} \\
\hline Active ingredient & $\mathrm{g} / \mathrm{ha}$ & & & \\
\hline Control & 0 & 5930 & 62.3 & 11.3 \\
\hline Bromoxynil : ioxynil & $100: 100$ & 6044 & 62.0 & 11.4 \\
\hline Bromoxynil : ioxynil & $150: 150$ & 6089 & 62.1 & 11.5 \\
\hline Bromoxynil : ioxynil & $200: 200$ & 6037 & 62.5 & 11.4 \\
\hline Dichlorprop-P : MCPA : mecoprop-P & $310: 160: 130$ & 6059 & 62.0 & 11.5 \\
\hline Dichlorprop-P : MCPA : mecoprop-P & $465: 240: 195$ & 6140 & 62.5 & 11.4 \\
\hline Dichlorprop-P : MCPA : mecoprop-P & $620: 320: 260$ & 6233 & 62.6 & 11.4 \\
\hline Florasulam & 2.5 & 6045 & 62.5 & 11.5 \\
\hline Florasulam & 3.75 & 5951 & 61.9 & 11.6 \\
\hline Florasulam & 5 & 6056 & 61.1 & 11.6 \\
\hline Fluroxypyr & 54 & 6192 & 63.1 & 11.2 \\
\hline Fluroxypyr & 108 & 6188 & 62.8 & 11.4 \\
\hline Fluroxypyr & 162 & 5986 & 61.8 & 11.6 \\
\hline MCPA : clopyralid : fluroxypyr & $400: 20: 80$ & 6050 & 61.7 & 11.6 \\
\hline \multirow[t]{2}{*}{ Tribenuron-methyl } & 10 & 6133 & 62.8 & 11.2 \\
\hline & S.E.M. & $152.8^{\text {ns }}$ & $0.68^{\mathrm{ns}}$ & $0.15^{\mathrm{ns}}$ \\
\hline
\end{tabular}

${ }^{\mathrm{ns}}$ Not statistically significant, $P>0.05$.

Data shown are combined means of early and late herbicide treatments $(n=8)$, since there were no significant differences between timings of treatment.

of fluroxypyr would not have resulted in satisfactory control in practice. The bromoxynil-ioxynil mix should be efficient against chickweed [16], but only the highest application rate resulted in acceptable control (Table 3). Nonetheless, it would represent an additional option to control sulfonylurearesistant chickweed.

The $\mathrm{N}$ content of the chickweed increased to $3.2 \%$ following tribenuron-methyl treatment, whereas it was $2.6 \%$ in control plants (data not shown). Thus, the $\mathrm{N}$ uptake of untreated chickweed was $16 \mathrm{~kg} / \mathrm{ha}$. However, the $\mathrm{N}$ uptake of tribenuron-methyl-treated chickweed was only $6 \mathrm{~kg} / \mathrm{ha}$, while for other treatments it was generally around $0.1 \mathrm{~kg} \mathrm{~N} / \mathrm{ha}$. Even though the N content in chickweed following tribenuron-methyl treatment probably increased due to the lower degree of intraspecific competition, as suggested by Cahill Jr. [17], lower number of plants accumulated less $\mathrm{N}$ due to lower total biomass (Table 3). A low level of intraspecific competition could also result in decreased root growth at low root densities [18], thus limiting the root surface area to a smaller volume of nitrogen-containing soil [19]. Although chickweed accumulated substantial amounts of nitrogen without weed control, this was not reflected in the barley grain yield, which was approximately $6100 \mathrm{~kg} / \mathrm{ha}$, its protein content, which was approximately $11.4 \%$, and its test weight, which was approximately 62.2 (Table 4 ). The different herbicide treatments did not affect barley yield or quality (Table 4). Hamouz et al. [20] also concluded that various weed control treatments had no effect on winter wheat (Triticum aestivum L.) yield. Earlier, Salonen and Erviö [21] reported that chemical weed control in general increased the grain yield of spring cereals. Moreover, a simple increased number of chickweed plants within the crop stand have led to significant decrease in yield of winter wheat [22].
Thus, it seems that the low chickweed canopy, below $100 \mathrm{~mm}$, might have negatively affected competition with barley. Even though the chickweed population did not affect barley yield during the year of the experiment, over the long term problems could arise, especially if less competitive, shorter, lodging sensitive, and slower growing crops are grown in the area without adequate weed management. Moreover, the chickweed seed bank was reported to respond directly to weed control treatments [23] and thus the species could increase so as to cause severe yield reductions if not managed properly.

\section{Conclusions}

In conclusion, the most effective active herbicide ingredients tested to control putative sulfonylurea-resistant chickweed populations were fluroxypyr, MCPA-clopyralid-fluroxypyr and dichlorprop-PMCPA-mecoprop-P mixtures. Good chickweed control was obtained at application rates of $80 \mathrm{~g} / \mathrm{ha}$ for fluroxypyr, and $130 \mathrm{~g} / \mathrm{h}$ a for mecoprop. Although, at least in the case of sulfonylurea resistance, other active ingredients can be used to control the weeds successfully, it is possible to avoid development of resistance through good crop management practices, including crop rotations and the use of herbicides mixtures using components from different groups. Rotations could be limited by sulfonylurearesistance developing in crops, such as Brassica species, and the limited range of herbicides on sale. Since the chickweed did not decrease barley yield or its quality, a more profound investigation should evaluate its management threshold taking also into account the economy. In this experiment, chickweed merely served as a nitrogen trap. 


\section{Conflict of Interests}

The authors declare that there is no conflict of interests regarding the publication of this paper.

\section{References}

[1] S. B. Powles and Q. Yu, "Evolution in action: plants resistant to herbicides," Annual Review of Plant Biology, vol. 61, pp. 317-347, 2010.

[2] P. J. Tranel and T. R. Wright, "Resistance of weeds to ALSinhibiting herbicides: what have we learned?” Weed Science, vol. 50, no. 6, pp. 700-712, 2002.

[3] C. A. Mallory-Smith, D. C. Thill, and M. J. Dial, "Identification of sulfonylurea herbicide-resistant prickly lettuce (Lactuca serriola)," Weed Technology, vol. 4, pp. 163-168, 1990.

[4] J. T. O’Donovan, G. M. Jeffers, D. Maurice, and M. P. Sharma, "Investigation of a chlorsulfuron-resistant chickweed [Stellaria media (L.) Vill.] population," Canadian Journal of Plant Science, vol. 74, no. 4, pp. 693-697, 1994.

[5] P. Kudsk, S. K. Mathiassen, and J. C. Cotterman, "Sulfonylurea resistance in Stellaria media [L.] Vill," Weed Research, vol. 35, no. 1, pp. 19-24, 1995.

[6] H. J. Beckie and X. Reboud, "Selecting for weed resistance: herbicide rotation and mixture," Weed Technology, vol. 23, no. 3, pp. 363-370, 2009.

[7] J. K. Norsworthy, S. M. Ward, D. R. Shaw et al., "Reducing the risks of herbicide resistance: best management practices and recommendations," Weed Science, vol. 60, pp. 31-62, 2012.

[8] W. K. Vencill, R. L. Nichols, T. M. Webster et al., "Herbicide resistance: toward an understanding of resistance development and the impact of herbicide-resistant crops," Weed Science, vol. 60, pp. 2-30, 2012.

[9] L. G. Holm, The Worlds' Worst Weeds: Distribution and Biology, University Press of Hawaii, Honolulu, Hawaii, USA, 1977.

[10] H. Fogelfors, "The competition between barley and five weed species as influenced by MCPA treatment," Swedish Journal of Agricultural Research, vol. 7, no. 3, pp. 147-151, 1977.

[11] H. H. Mann and T. W. Barnes, "The competition between barley and certain weeds under controlled conditions IV. Competition with Stellaria media," Annals of Applied Biology, vol. 37, pp. 139148, 1950.

[12] P. J. W. Lutman, P. Bowerman, G. M. Palmer, and G. P. Whytock, "Prediction of competition between oilseed rape and Stellaria media," Weed Research, vol. 40, no. 3, pp. 255-269, 2000.

[13] L. Hämet-Ahti, “The boreal zone and its biotic subdivision," Fennia, vol. 159, pp. 69-75, 1981.

[14] U. Meier, Ed., Growth Stages of Mono-and Dicotyledonous Plants: $B B C H$ Monograph, Federal Biological Research Centre for Agriculture and Forestry, 2001, http://www.jki.bund.de/ fileadmin/dam_uploads/_veroeff/bbch/BBCH-Skala_englisch.pdf.

[15] R. Marshall, R. Hull, and S. R. Moss, "Target site resistance to ALS inhibiting herbicides in Papaver rhoeas and Stellaria media biotypes from the UK," Weed Research, vol. 50, no. 6, pp. 621630, 2010.

[16] P. Kudsk and S. K. Mathiassen, "Herbicid resistens-status," DJF Rapport, vol. 99, pp. 127-139, 2004.

[17] J. F. Cahill Jr., "Lack of relationship between below-ground competition and allocation to roots in 10 grassland species," Journal of Ecology, vol. 91, no. 4, pp. 532-540, 2003.
[18] P. J. Kramer and J. S. Boyer, Relations of Plants and Soils, Academic Press, San Diego, Calif, USA, 1995.

[19] A. H. Fitter, "Effects of nutrient supply and competition from other species on root growth of Lolium perenne in soil," Plant and Soil, vol. 45, no. 1, pp. 177-189, 1976.

[20] P. Hamouz, K. Hamouzová, J. Holec, and L. Tyšer, "Impact of site-specific weed management on herbicide savings and winter wheat yield," Plant, Soil and Environment, vol. 59, pp. 101-107, 2013.

[21] J. Salonen and L. R. Erviö, "Efficacy of chemical weed control in spring cereals in Finland," Weed Research, vol. 28, no. 4, pp. 231-235, 1988.

[22] E. Stasinskis, "Effect of preceding crop, soil tillage and herbicide application on weed and winter wheat yield," Agronomy Research, vol. 7, pp. 103-112, 2009.

[23] A. Légère, F. C. Stevenson, D. L. Benoit, and N. Samson, "Seedbank-plant relationships for 19 weed taxa in spring barleyred clover cropping systems," Weed Science, vol. 53, no. 5, pp. 640-650, 2005. 


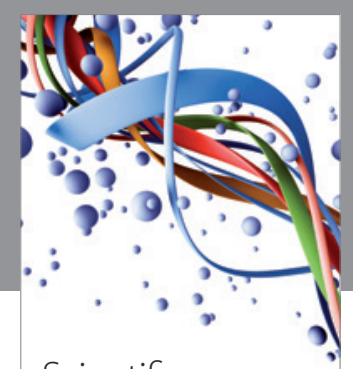

Scientifica
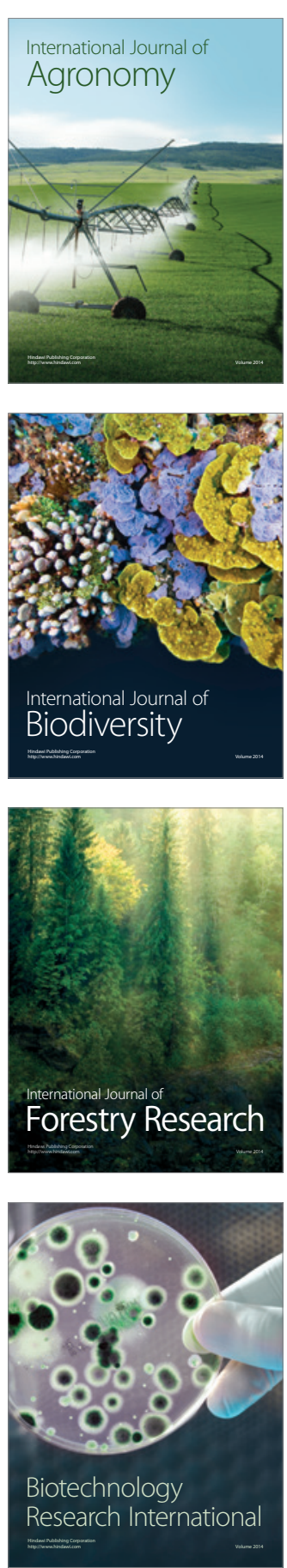
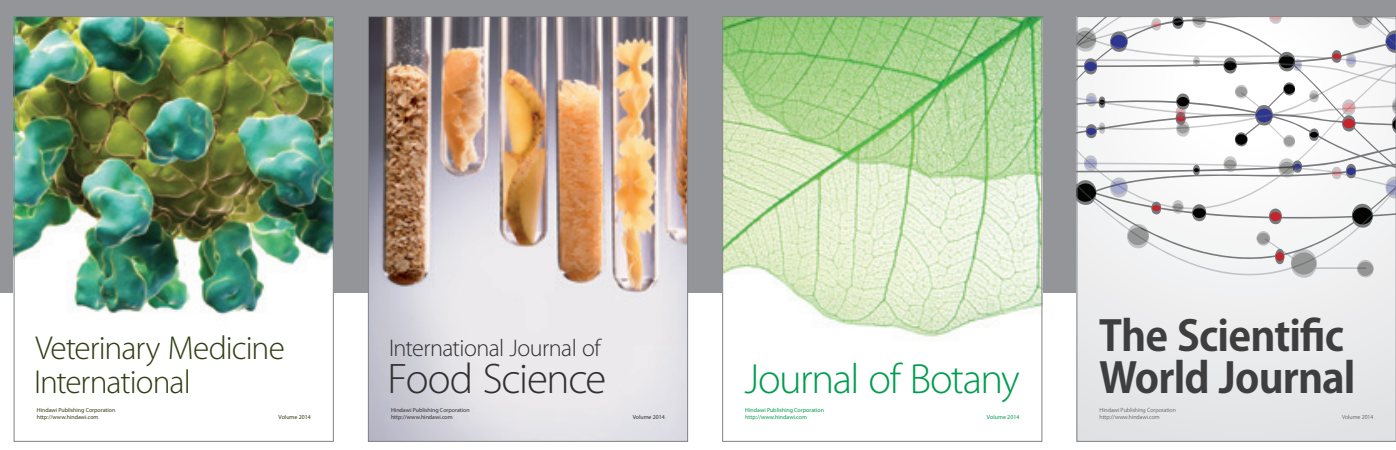

The Scientific World Journal
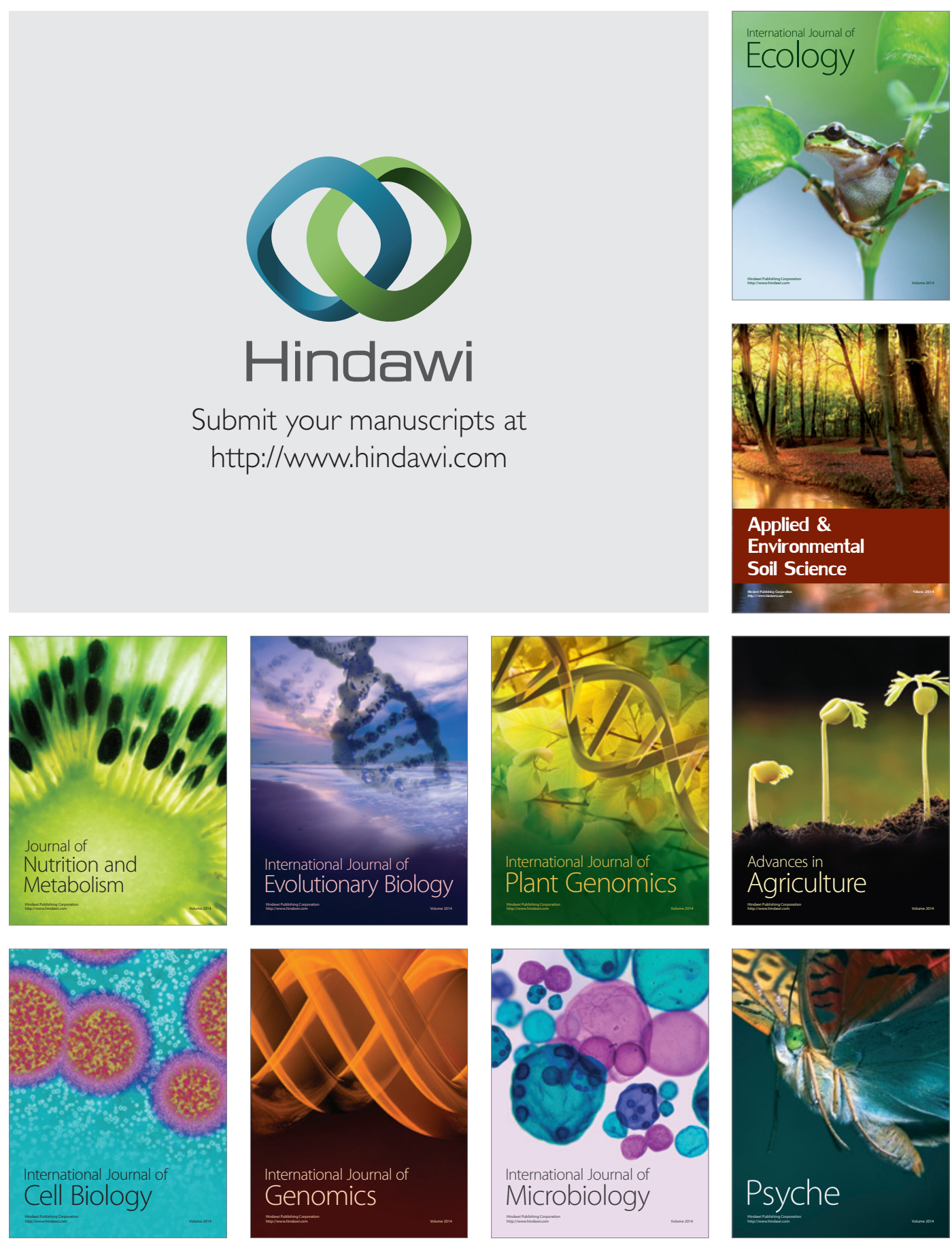